\title{
mssaico
}

Novos "sujeitostorcedorxs":

trajetórias e estratégias de visibilidade da

\section{Galo Queer,}

Bambi Tricolor e

\section{Palmeiras Livre}

\section{Mauricio Rodrigues Pinto $^{1}$ \\ Marco Bettine de Almeida ${ }^{2}$}

1 Mestre pelo Programa Mudança Social e Participação Política pela USP. Graduado em História pela Universidade de São Paulo (USP), com especialização em Sociopsicologia pela FESPSP. E-mail: maorodrigues9@gmail.com

2 Professor Associado da USP na Escola de Artes, Ciências e Humanidades (EACH-USP). Professor do Programa Interdisciplinar de Pós-graduação em Mudança Social e Participação Política. E-mail: marcobettine@gmail.com

New "subject-fans": trajectories and strategies of visibility of Galo Queer, Bambi Tricolor and Palmeiras Livre http://dx.doi.org/0.12660/rm.v9n14.2018.73996 


\section{Resumo:}

A proposta deste artigo é investigar as trajetórias de movimentos de torcedorxs contemporâneos que se posicionam politicamente contrários à homofobia e à misoginia no futebol brasileiro. Por meio do acompanhamento de suas interações na rede social Facebook e também a partir de relatos obtidos em entrevistas de história oral com seus integrantes, são analisadas as trajetórias da Galo Queer (formada por torcedorxs do Clube Atlético Mineiro), Bambi Tricolor (que reúne torcedorxs do São Paulo Futebol Clube) e Palmeiras Livre (coletivo de torcedorxs da Sociedade Esportiva Palmeiras) e algumas de suas estratégias de visibilidade.

Palavras-chave: futebol; homofobia; machismo; torcidas queer; facebook.

\section{Abstract:}

The purpose of this article is to investigate the trajectories of movements of contemporary fans who are politically opposed to homophobia and misogyny in Brazilian soccer. Through the monitoring of their interactions in the social networking site Facebook and also from reports obtained in oral history interviews with their members, it'll be analyzed the trajectories of Galo Queer (formed by fans of Clube Atlético Mineiro), Bambi Tricolor (that unites supporters of the São Paulo Futebol Clube) and Palmeiras Livre (a collective of fans from the Sociedade Esportiva Palmeiras) and their strategies of visibility.

Keywords: football; homophobia; male chauvinism; queer football supporters, facebook. 


\title{
Introdução
}

\begin{abstract}
Está muito equivocado quem, indivíduo ou organização, acredita deter o monopólio da paixão e do modo certo de torcer por um clube. Nós temos muita vontade de ver e exibir cartazes, faixas, bandeiras com mensagens afirmativas à causa LGBT nas arquibancadas, e não necessariamente como uma torcida organizada. Como torcida, simplesmente. Todo o fundamento de manter uma campanha anti-homofobia, afinal, é essa: conquistar mais liberdade, mais espaço pra diversidade, diluir a naturalidade com que o preconceito se manifesta ali, de modo geral (Extraído de postagem da Bambi Tricolor, de 22/10/2013) ${ }^{1}$.
\end{abstract}

Trinta anos após o fim da Coligay $^{2}$, a primeira e única torcida declaradamente gay a marcar presença nas arquibancadas dos estádios brasileiros, inicia-se em 2013 uma nova movimentação envolvendo torcedoras e torcedores de alguns dos principais times de futebol do Brasil, novamente questionando a norma de que o futebol é um jogo exclusivo "pra machos". Esses movimentos, que se apresentam à época como torcidas livres e queer, construíram a sua visibilidade por meio de páginas no site de rede social Facebook ${ }^{3}$. Além de espaços de exaltação ao time "de coração", também se constituíram em canais de produção e divulgação de conteúdos que visavam desnaturalizar as ofensas e as violências misógina e homofóbica que são reiteradas no campo futebolístico, e, questionar o lugar de abjeção ao qual são usualmente relegadas as mulheres e as pessoas $\mathrm{LGBT}^{4}$.

Neste artigo, trataremos das trajetórias e das estratégias de visibilidade adotadas por Galo Queer, a Bambi Tricolor e o Palmeiras Livre, por meio de análises das suas práticas discursivas e interações expressas no ciberespaço, como também pelos relatos de integrantes desses movimentos. É possível afirmar que integrantes desses movimentos buscam para si o reconhecimento como sujeitos-torcedorxs ${ }^{5}$, na medida em que combinam a

\footnotetext{
${ }^{1}$ Disponível em:

https://www.facebook.com/BambiTricolor/photos/a.456985997715246.1073741828.456955007718345/54085 5135994998. Acesso em: 01/10/2017.

${ }^{2}$ A Coligay foi uma torcida do Grêmio Foot Ball Porto Alegrense (RS), que existiu entre os anos de 1977 e 1983. Criada por Volmar Santos, na época dono da boate gay Coliseu, localizada em Porto Alegre, é reconhecida como a primeira e única torcida gay a marcar presença nas arquibancadas dos estádios brasileiros.

${ }^{3}$ O Facebook (originalmente, thefacebook) é um site de rede social criado por Mark Zuckerberg em 2004, enquanto este era aluno da Universidade de Harvard. Atualmente, o Facebook é o maior site de rede social do planeta, tendo quase 2 bilhões de usuários ativos em todo mundo.

4 LGBT é a sigla de Lésbicas, Gays, Bissexuais, Travestis, Transexuais e Trangêneros. No Brasil, a alteração do termo GLBT em favor de LGBT foi aprovada na 1a Conferência Nacional GLBT, realizada em Brasília, em 2008, com o propósito de valorizar as lésbicas no contexto da diversidade sexual e também de aproximar o termo brasileiro com o termo predominante em várias outras culturas.

${ }^{5}$ É deliberada a opção pelo uso da linguagem não-binária em "torcedorxs" para se referir aos integrantes dos movimentos e coletivos contrários ao machismo e à homofobia no futebol no decorrer deste artigo. Trata-se de
} 
paixão e a torcida pelo time de coração com o ativismo político. A partir de práticas discursivas, em suas respectivas páginas no Facebook, que questionam a norma que estabelece uma masculinidade hegemônica, cisgênera e heterossexual, como o modelo que os atores participantes do campo futebolístico devem se adequar, a ponto de se tornar comum a expressão de que futebol no Brasil é um "jogo pra macho".

Para Butler (2016), as normas reguladoras, em um determinado contexto, produzem indivíduos que são reconhecidos como sujeitos e também os não sujeitos (seres abjetos, inadequados perante a norma regulatória). Estes movimentos de torcedorxs reivindicam também ser reconhecidos como sujeitos pelo campo futebolístico, mas não pelo enquadramento à masculinidade hegemônica ${ }^{6}$ que se consolidou no futebol brasileiro, mas pelo rompimento e a desconstrução dessa norma. No entanto, conforme será discutido adiante, tal posicionamento faz com que esses movimentos de torcedorxs encontrem grande resistência e rejeição, muitas vezes expressas na forma de ofensas públicas nas páginas que mantêm e também por meio de atos de intimidação aos seus integrantes, fazendo com que as pessoas ligadas a esses movimentos não se sintam seguras para realizarem a ocupação de espaços nas arquibancadas ou mesmo para promoverem reuniões em locais públicos.

Para aprofundar o entendimento sobre o surgimento e a atuação desses grupos, além da análise das postagens no Facebook, serão utilizados relatos de integrantes desses movimentos, obtidos por meio de entrevistas de história oral temáticas ${ }^{7}$ (MEIHY, 1994). As entrevistas foram importantes para aprofundar o entendimento sobre as motivações que levaram essas pessoas a criarem e/ou a fazerem parte dessas comunidades virtuais, além de possibilitar conhecer os seus pontos de vista sobre o ativismo que realizam e as reações que despertaram no campo futebolístico.

\section{Trajetórias das torcidas livres e queer: o torcedor como forma de ativismo político}

uma forma de resaltar o posicionamento político desses grupos contrário à norma que naturaliza homens cisgêneros e heterossexuais como os legítimos "torcedores" do futebol.

6 "As masculinidades hegemônicas podem ser construídas de forma que não correspondam verdadeiramente à vida de nenhum homem real. Mesmo assim esses modelos expressam, em vários sentidos, ideais, fantasias e desejos muito difundidos. Eles oferecem modelos de relações com as mulheres e soluções aos problemas das relações de gênero. Ademais, eles se articulam livremente com a constituição prática das masculinidades como formas de viver as circunstâncias locais cotidianas. Na medida em que fazem isso, contribuem para a hegemonia na ordem de gênero societal". (CONNELL; MESSERCHIMIDT, 2013, p. 253).

${ }^{7}$ As entrevistas fizeram parte do projeto "Pelo Direito de Torcer, realizado em com o Museu do Futebol e o Centro de Referência do Futebol Brasileiro (CRFB), que tem como objetivo "mapear grupos e movimentos de torcedorxs contrários à norma de que o futebol é jogo 'pra macho', assim como de conhecer as suas vivências, discursos e embates com o campo futebolístico"7 (PINTO; BONFIM, 2017, p. 10). Neste artigo, são aproveitados relatos das seguintes entrevistas: Thaís Nozue e Erick Miyasato (Palmeiras Livre), em 18/11/2016; Nathália Duarte (Galo Queer), em 15/02/2017. Não foi possível a realização de entrevista com integrante da Bambi Tricolor. As transcrições das entrevistas na íntegra estão disponíveis no banco de dados online do CRFB em: http://dados.museudofutebol.org.br. 
Durante uma partida do Atlético Mineiro válida pela Libertadores da América, em 2013 - que viria a ser conquistada pelo Galo -, a atleticana Nathalia experimentou uma sensação de grande incômodo diante de uma situação aparentemente tão comum e natural para a grande maioria dos presentes naquele jogo disputado no Estádio Independência, em Belo Horizonte. Na ocasião, acompanhada de amigos, ela via a torcida do Galo entoar cantos e gritos homofóbicos contra os torcedores do Arsenal de Sarandi, time da Argentina. O estranhamento e a desnaturalização da carga de violência presente nos cantos e gritos dirigidos ao adversário, somada à vivência de ser mulher em um espaço de sociabilidade predominantemente masculino, foram determinantes para que, em 09/04/2013, ela decidisse criar a página da Galo Queer ${ }^{8}$ no site Facebook, primeira comunidade a se apresentar como torcida queer:

Tem dois momentos que ficaram mais gravados. Um deles, em um jogo contra o Arsenal (ARG), pela Libertadores, e aí o estádio inteiro começou a gritar "Maricón!" para o outro time. Eu sabia que essas coisas aconteciam, mas me chocou um pouco a violência das pessoas ao dizerem isso, como se fosse uma coisa realmente muito ofensiva e o que me chocou mais foi o fato dos meus amigos terem participado. Fiz questão de sentar para não participar daquilo, e eu olhava em volta e não tinha ninguém que estava achando aquilo minimamente estranho. Aí teve um dia que estava no bar, com os amigos, eu falei: "Fiquei com vontade de criar esse movimento." As pessoas da mesa ficaram escutando. "Ah, legal...", mas ninguém botou muita fé e nem se dispôs a fazer junto. "Bom, vou fazer sozinha, então". Hoje em dia é relativamente fácil, porque no Facebook, você simplesmente cria uma página, a coisa existe. E aí eu fiz a página e achei legal a ideia do queer, porque a minha ideia não era fazer uma torcida gay, por exemplo, ou só um movimento contra a homofobia, mas eu queria abordar a questão das mulheres também, mesmo heterossexuais. Queer era um nome abrangente, além de sonoro e foi daí que surgiu. Eu inocentemente criei a página e divulguei no meu perfil, para os meus amigos. Falei assim: "Ah, umas 100 pessoas vão curtir, vão achar legal e é isso mesmo". Criei a página, fui dormir, de repente, quando acordei era ligação de todos os jornais querendo falar comigo, já tinha 1000 pessoas curtindo, e 1000 pessoas me escrevendo, querendo falar, querendo participar... Foi uma loucura! E ao mesmo tempo, as outras torcidas foram surgindo, acho que 48 horas depois já havia umas cinco torcidas de outros times e foi só aumentando. Foi uma reação muito desproporcional, muito maior do que eu imaginava... ${ }^{9}$ (Nathalia, Galo Queer).

\footnotetext{
${ }^{8}$ Comunidade criada em 09/04/2013. O texto de apresentação da página da Galo Queer é o seguinte: “Galo Queer é o movimento anti-homofobia e antissexismo no futebol dos torcedores do Clube Atlético Mineiro, vulgo Galo Doido. Porque paixão pelo Galo não tem nada a ver com intolerância". A página possui 2035 curtidas (dado de 26/06/2017). Endereço da página: https://www.facebook.com/Galo-Queer-941232029242434/.

${ }^{9}$ Dentre as reportagens realizadas após a criação da Galo Queer, cito matéria postada no site ESPN.com.br, intitulada “A corajosa 'Galo Queer': cientista social funda movimento anti-homofobia na torcida do AtléticoMG”, de 11/04/2013. Disponível em: http://espn.uol.com.br/noticia/322413_a-corajosa-galo-queer-cientista-
} 
A alusão ao queer presente na fala de Nathalia é importante para a compreensão do caráter contestatório dos grupos de torcedorxs que começaram a se articular e aparecer por meio de comunidades no Facebook. A palavra queer, cujo significado original na língua inglesa corresponde a "estranho", "excêntrico", adquiriu conotação de xingamento, injúria dirigida especialmente contra a população homossexual nos Estados Unidos, principalmente por causa da crise social provocada pela epidemia de HIV/Aids, no início da década de 1980.

No final da década de 1980 e início da década de 1990, o termo foi apropriado por coletivos formados pela militância homossexual, pessoas portadoras de HIV, lésbicas, trabalhadores do sexo e profissionais de saúde, amigos e familiares de homossexuais, dando forma a Queer Nation, constituída pela "parte da nação que foi rejeitada, humilhada, considerada abjeta, motivo de desprezo e nojo, medo de contaminação" (MISKOLCl, 2013, p. 24). A apropriação feita pela Queer Nation teve o objetivo de deslocar e ressignificar a conotação ofensiva que era até então atribuída à palavra.

De acordo com a fala de Nathalia, a proposta da Galo Queer não era a de ser uma torcida gay buscando a sua aceitação em um meio homofóbico e misógino, nem mesmo resumia-se a ser "só um movimento contra a homofobia", maneiras pelas quais muitas pessoas interpretaram (e ainda interpretam) o movimento. MISKOLCI (2013), ao analisar a dimensão política do ativismo queer, afirma que este "não é uma defesa da homossexualidade, é a recusa dos valores morais violentos que instituem e fazem valer a linha da abjeção, essa fronteira rígida entre os que são socialmente aceitos e os que são relegados à humilhação e ao desprezo coletivo" (MISKOLCl, 2013, p. 25).

Nos dias seguintes à criação da Galo Queer, outras comunidades similares a ela surgiram no Facebook. Uma delas foi a página do hoje coletivo Palmeiras Livre ${ }^{10}$, resultado da articulação de um grupo de palmeirenses de diferentes partes do Brasil. Thaís, uma das moderadoras da comunidade, relata a inspiração na Galo Queer e explica como se deu a constituição da Palmeiras Livre, falando também sobre o que a motivou a fazer parte do grupo que faz a moderação dos conteúdos postados:

É engraçado que o coletivo nasceu com dois membros de São Paulo e o resto de fora. Porque tinha a Ligy, a Ana e a Lorraine, todas do Norte do país, e depois entrou o William, que também morava em João Pessoa, não estava em São Paulo ainda. Só tinha o Felipe e eu de São Paulo, e a Amara,

social-funda-movimento-anti-homofobia-na-torcida-do-atletico-mg. Acesso em 27/09/2016. Outra matéria, de 24/04/2013, já tratando das outras páginas que seguiram o exemplo da Galo Queer, foi publicada pelo portal da Empresa Brasileira de Comunicação (EBC), com o título "Torcidas organizadas gays usam redes sociais para enfrentar preconceito no futebol". Disponível em: http://www.ebc.com.br/esportes/2013/04/torcidasorganizadas-gays-usam-redes-sociais-para-enfrentar-preconceito-no-futebol. Acesso em 31/05/2016.

${ }^{10}$ Página criada em 12/04/2013. Apresenta-se como: "Movimento anti-homo e transfobia, contra o racismo e todo tipo de sexismo (os machismos e misoginias em especial), destinado à torcida que mais canta e vibra. Porque paixão pelo Palmeiras não tem nada a ver com intolerância". A comunidade conta com 7429 curtidas (dado de 26/06/2017). Endereço da página: https://www.facebook.com/PalmeirasLivre. 
que era de Campinas, e depois saiu. Era uma coisa super espalhada. Eu vi crescer a questão do Galo Queer e, de repente, alguém dentro da página comentou alguma coisa e colocou que existia a Palmeiras Livre. Eu falei: "Nossa, que legal, vou lá". Eu vi que existia e era para as pessoas colaborarem. Eu já mandei mensagem no inbox e me envolvi. Acho que na primeira semana de fundação da página já estava envolvida e comecei a fazer as coisas. (Thaís, Palmeiras Livre).

A sua fala ajuda também a compreender como se dá articulação de grupos que fazem ativismo político nas redes sociais virtuais. Apesar das páginas serem acompanhadas e curtidas por milhares de pessoas, esses coletivos e movimentos são majoritariamente constituídos por um núcleo atuante reduzido, formado por pessoas com faixa etária predominante entre os 20 e 35 anos, público que mais se apropria das redes sociais digitais com fins de participação em movimentos políticos e sociais (OMENA, 2015).

No caso do Palmeiras Livre, apesar da distância física, a reunião do grupo inicial que criou a página no Facebook foi viabilizada pelo acesso a um mesmo site de rede social e por laços sociais em comum. Dentre eles, a paixão e a torcida pelo Palmeiras combinadas ao posicionamento político contrário à homofobia e ao machismo e ao sentimento de que era preciso fazer algo para enfrentar tais violências no futebol. Segundo RECUERO (2009, p. 44), "a comunicação mediada por computador apresentou às pessoas formas de manter laços sociais fortes, mesmo separadas a grandes distâncias (...). Essa desterritorialização dos laços é consequência direta da criação de novos espaços de interação".

No dia 14/04/2013, era lançada a página da Bambi Tricolor ${ }^{11}$. O próprio nome do movimento - que faz referência ao "apelido"12 rejeitado pelos são paulinos e que se tornou a principal ofensa usada por torcedores adversários para referirem-se ao São Paulo -, mostra um alinhamento de seus integrantes ao ativismo queer, por meio da apropriação e positivação de um termo que tem conotação de ofensa homofóbica. Ao fazer tal ressignificação, o propósito foi o de questionar porque ser "bambi" (ou ser associado à homossexualidade) tem de ser encarado como uma ofensa ou um estigma abjeto. Aline, uma

\footnotetext{
${ }^{11}$ A Bambi Tricolor tem o seguinte texto de apresentação: “Paixão pelo futebol, amor ao clube e até rivalidade entre adversários não tem nada a ver com homofobia. Se, até agora, Bambi foi um apelido usado para discriminar, por que não adotá-lo com orgulho e desarmar o preconceito? Pelo SPFC livre". Comunidade que conta com 3674 curtidas (dado de 01/08/2017). Endereço da página: https://www.facebook.com/BambiTricolor/.

12 "Bambi" é um termo que faz referência ao cervo que dá nome a um filme produzido pelos estúdios Disney, na década de 1940. Atribui-se ao ex-jogador corinthiano Vampeta, a popularização do termo, no início da década de 2000. Durante uma coletiva de imprensa, o jogador revelou o "apelido" que usava para provocar os seus amigos que, à época, jogavam pelo São Paulo: “O Corinthians tem o gambá, o Santos tem a baleia, o Palmeiras tem o porco e o São Paulo precisava adotar um animal de estimação. Essa história do bambi já existia e eu só acordei o gigante adormecido". Fala extraída da matéria "Ídolo no Corinthians, Vampeta explica o apelido de 'bambi' que deu para o São Paulo". Disponível em: http://torcedores.uol.com.br/noticias/2016/11/idolo-nocorinthians-vampeta-explica-o-apelido-de-bambi-que-deu-para-o-sao-paulo. Acesso em 02/05/2017.
} 
das criadoras e principal interlocutora da página, reafirma esse propósito ao comentar o porquê da escolha pelo "Bambi Tricolor":

\begin{abstract}
Quando nós dizemos "vamos assumir o Bambi" pensando em mudar os termos dessa discussão, quando dizemos que o estigma da homossexualidade não pode, em si, ser recebido como ofensa por mais que seja formulado e proferido como tal, somos acusados de todo o tipo de coisa, que vai de ingenuidade, a estupidez, a sermos rivais humilhando e desrespeitando o clube. Uma das coisas que nos foram ditas é que se tivéssemos escolhido o nome SPFC Livre, nós receberíamos mais apoio e adesões. O que, para nós, aponta a ambiguidade da situação dos sãopaulinos diante da homofobia. Como defender a causa LGBT sem "piorar" o estigma de sermos uma torcida gay, ou torcedores de um time gay? A própria configuração desse "impasse" já expõe o quanto nós, como sociedade, não temos clareza sobre o problema, e quão naturalizada é a homofobia ${ }^{13}$.
\end{abstract}

O surgimento dessas comunidades está inserido no contexto político brasileiro de 2013, ano marcado por forte efervescência política e por manifestações e protestos em diversas partes do país, que culminaram nas "jornadas de junho". Essas manifestações inicialmente estavam focadas na questão do transporte público urbano e do direito à cidade. A adesão de grande contingente popular fez com que os protestos passassem também a enfocar outros problemas sociais do país, abarcando também o futebol, principalmente por conta dos elevados gastos públicos na construção de estádios e da infraestrutura para a realização da Copa das Confederações, em 2013, e da Copa do Mundo de Futebol Masculino, em 2014:

As manifestações ganharam conotação popular à medida que apareceram as palavras de ordem contra os gastos com a Copa do Mundo de 2014 e as Olimpíadas de 2016, sobretudo nos locais em que ocorreram os jogos da Copa das Confederações. O chamado "branqueamento" dos modernos templos do futebol construídos para 2014, (...) parece ter ocasionado uma justificada revolta nos "de baixo". Com a crítica aos dispêndios para o calendário esportivo, entrava em cena uma segunda bandeira de esquerda, após a da redução das tarifas. Afinal, o que está em jogo é a destinação de dinheiro público para construir estádios luxuosos e rendosos em termos de negócios, mas depois pouco úteis, em um país onde os pobres não têm esgoto, atendimento médico, transporte aceitável, segurança pública e, agora, para cúmulo da ironia, passaram a ser excluídos também do próprio futebol (SINGER, 2013).

13 Entrevista concedida para o blog "Futepoca: Futebol, Cachaça e Política". Disponível em: http://www.futepoca.com.br/2013/08/bambi-tricolor-em-questoes-que-envolvem.html. Acesso em 26/08/2017. 
Muitas dessas manifestações e protestos públicos tiveram como grande diferencial as articulações realizadas através de sites e aplicativos de rede social, sendo que muitos atos foram convocados pelo Facebook. A internet e as redes sociais virtuais possibilitaram a um grande contingente de pessoas expressarem diretamente as suas insatisfações e posicionamentos políticos, constituindo-se em canais potentes para a "disseminação de descontentamentos compartilhados pela maioria da população dos grandes centros urbanos" (OMENA, 2015, p. 210-211).

As falas a seguir de Nathalia e Thaís ajudam a compreender a relação desses torcedorxs e das páginas recém-criadas com esse contexto de efervescência política, no qual o futebol constituiu-se em um potente espaço de debates e de questionamentos políticos. Evidenciam também os seus processos de formação política, exteriores ao futebol, provenientes de experiências em outros movimentos políticos e sociais, especialmente ativismos em defesa da igualdade de gênero e dos direitos da população LGBT. Nas falas de ambas, fica explícita a intenção deliberada de levar essa bagagem de ativismos políticos para o futebol:

Foi uma época em que eu estava numa fase de ativismo político muito forte. Em 2013, quando eu criei a Galo Queer, eu voltei de um intercambio na Alemanha, muito engajada, participava de coletivos feministas e entrei num coletivo de mobilidade urbana, o Tarifa Zero, estava muito em contato com todos os movimentos políticos da cidade [Belo Horizonte], então, nessa época tava todo mundo imerso, 2013 foi muito intenso. Por algumas semanas a vida era só aquilo, havia uma variedade grande de pautas ainda ali, nas manifestações, a gente não sabia direito o que era aquilo. Politicamente foi um momento intenso, porque eu entrei em contato com o feminismo de forma mais forte. Foi na Alemanha que comecei a estudar gênero e conheci pessoas que eram muito ativas politicamente também. Isso formou muito a minha visão. Na época eu estava com os óculos do gênero total, só via isso, só conversava sobre isso. Quando eu voltei ao Brasil e fui ao estádio, foi muito violento para mim, estando com esse olhar (Nathalia, Galo Queer).

2013 foi um ano em que aconteceram várias coisas. Nosso coletivo nasceu em abril, antes das jornadas de junho. Mas no ano anterior eu já tinha participado muito de movimentos políticos abordando questões de gênero. Aí eu vi a oportunidade de somar as duas coisas, ainda mais porque o Palmeiras tinha sido campeão e rebaixado. Eu vi a oportunidade de juntar as duas coisas. Porque o futebol está ligado com as pessoas, a sociedade e a política. Eu entrei, achei a ideia super bacana. Ela foi amadurecendo e até hoje ela vem se transformando. Não me puseram condição nenhuma. Não é um compromisso que eu tenho que postar tantas coisas por dia ou por 
semana. É só mesmo envolvimento e a vontade mesmo de mudar, de transformar alguma coisa, de fazer as pessoas refletirem um pouco, se apropriarem do espaço da rua, entenderem um pouco de política. (Thaís, Palmeiras Livre).

\section{Estratégias de visibilidade e as resistências do campo futebolístico}

O episódio do selinho dado pelo jogador Émerson Sheik ${ }^{14}$, em agosto de 2013, contribuiu para impulsionar a visibilidade dos movimentos de torcedorxs contrários ao machismo e à homofobia para além das redes sociais. Todos eles, à época, se posicionaram acerca do assunto e repercutiram também os seus desdobramentos. A partir da repercussão do episódio e da discussão instalada sobre a homofobia no futebol, diversas reportagens foram realizadas por veículos de comunicação da grande mídia (das mídias impressa e eletrônica e também por canais de televisão) e integrantes desses movimentos passaram a ser reconhecidos como interlocutores desse debate no futebol.

Em reportagem da revista Placar $^{15}$, de setembro de 2013, fica explícito também o esforço mobilizado por atores estabelecidos do campo futebolístico em rejeitar o compartilhamento de uma identidade torcedora com esses "sujeitos-torcedorxs". Ao ser convidado a opinar sobre a Bambi Tricolor, um diretor da torcida organizada Independente disse: "Essa torcida não existe, chapa! Não significa nada para nós". A resposta dada pela Bambi Tricolor, em postagem feita dias depois, buscou mostrar que o esforço feito em ignorar a existência do movimento era, na verdade, uma demonstração do incômodo com a visibilidade recente alcançada pela Bambi Tricolor:

Ousamos acreditar que esta declaração diz exatamente o que não quer dizer: que a Bambi Tricolor tanto existe como significa algo, e que essa existência, como seu significado, exigem um esforço tremendo para serem ignorados - daí a quantidade de ofensas e ameaças de agressão física e até morte que recebemos, constantemente. Quanto mais resistente uma sociedade se mostra aos discursos combativos do preconceito e da

\footnotetext{
${ }^{14}$ No dia 18 de agosto de 2013, o jogador de futebol Emerson Sheik, à época atacante do Corinthians, postou uma foto na sua página pessoal na rede social Instagram, na qual dava um selinho em um amigo. A foto era acompanhada da seguinte mensagem: "Tem que ser muito valente para celebrar a amizade sem medo do que os preconceituosos vão dizer. Tem que ser muito livre para comemorar uma vitória assim, de cara limpa, com um amigo que te apoia sempre...". O episódio foi repercutido na reportagem "Sheik comemora vitória do Corinthians com selinho em amigo", feita pelo portal Uol Esportes. Disponível em: http://uolesporte.blogosfera.uol.com.br/2013/08/19/sheik-comemora-vitoria-do-corinthians- com-selinho-emamigo/. Acesso em 10/10/2014.

15 "Porta da Esperança: O selinho de Sheik poderia ser um marco para encorajar jogadores a saírem do armário, mas só reforçou a homofobia no futebol”. Revista Placar, n 1382, setembro/2013, p. 31-36.
} 
violência, mais esses discursos se mostram necessários e precisos em sua crítica ${ }^{16}$.

É recorrente que esses movimentos e coletivos tenham a sua prática torcedora questionada e sejam inferiorizados por ditos "torcedores de verdade". Em razão disso, estes também se preocupam em fazer postagens nas quais explicitam a paixão pelo time, acompanham e comentam o seu desempenho em partidas e competições disputadas, dessa forma buscando mostrar o engajamento pelos times que torcem.

No caso da página da Palmeiras Livre, por exemplo, a estratégia de fazer postagens sobre as atuações, o desempenho do time e abordar episódios e personagens importantes da história do clube, além de mostrar que se trata de um coletivo feito por torcedorxs do Palmeiras, visa também estabelecer diálogo com uma gama maior de pessoas que gostam de futebol (especialmente palmeirenses), abrindo a possibilidade para que elas pensem nas questões políticas implicadas no futebol:

Eu entrei para o coletivo com umas propostas. "Ah, vamos colocar algum texto aí sobre o Palmeiras, algumas curiosidades históricas aí do time. É aniversário da Arrancada Heróica, vamos botar um texto sobre a Arrancada Heróica". Porque essa foto vai ser compartilhada, alguém vai chegar nessa foto. "Ah, é alguma coisa do Palmeiras". Ela vai ler e tomar conhecimento da página e das ideias que a gente defende e falar: "Nossa, tem uma página aqui que é diferente, vou dar uma olhada, vou chegar mais", "Nossa, existem torcedores que pensam assim? Que legal!". Eu acho que a coisa boa da internet é isso, ela é um canal. A gente está ali, é uma galera que existe. Se não está presente no espaço físico do futebol, então esteja presente na internet, porque essas pessoas existem, elas estão aí, só não podem circular pela arquibancada livremente por uma série de questões (Erick, Palmeiras Livre).

Além da apropriação da identidade "torcedorxs", outra estratégia que fez com que esses movimentos ganhassem visibilidade e firmassem o seu posicionamento político de questionamento à ideia do futebol como um reduto masculino, cisgênero e heterossexual, foi a vinculação de referências e símbolos dos movimentos LGBT e da diversidade de gênero e sexual aos símbolos, escudos, cores e nomes dos seus respectivos times. No entanto, como exposto anteriormente, no caso da apropriação do "bambi" pela Bambi Tricolor, as transgressões dos símbolos dos clubes feitas por esses movimentos encontraram forte

\footnotetext{
16 Extraído de postagem da comunidade Bambi Tricolor, de 22/10/2013, que recebeu 97 curtidas, 14 comentários $\quad$ e $16 \quad$ compartilhamentos. Disponível em: https://www.facebook.com/BambiTricolor/photos/a.456985997715246.1073741828.456955007718345/54085 5135994998/. Acesso em 30/09/2017.
} 
rejeição. Para FRANCO JUNIOR (2007, p. 216), tal reação pode ser explicada pelo fato de que o "escudo é praticamente a síntese material do clube, sua corporificação, daí a atenção e tensão maior de que é cercado".

A fala de Nathalia mostra como o fato de colorir o escudo do Atlético com as cores do arco-íris - fazendo referência à bandeira do movimento LGBT - e usá-lo como identidade visual da Galo Queer, ao mesmo tempo que contribuiu para a visibilidade do movimento, criou tensões e questionamentos até por pessoas que se declaravam favoráveis à diversidade sexual e sem preconceitos. Tal fato evidencia uma resistência de que tal debate seja realizado no futebol e o temor de que a visibilidade de tais ações faça com que um time fique marcado pelo mesmo "estigma" que recaiu, por exemplo, sobre o São Paulo:

Eu muito inocentemente peguei o escudo do Galo e pensei: "Bem, vou colorir o escudo". E isso deu uma polêmica que talvez tenha sido maior do que a própria criação do movimento. Várias pessoas falaram: "Sim, eu apoio o movimento, mas isso de subverter o escudo do Galo, isso aí é imperdoável, isso aí não pode..." Nossa, foi uma loucura! A maioria das ameaças e dos xingamentos eram mensagens para página ou posts na própria página - depois a gente desativou a possibilidade das pessoas publicarem lá por causa disso, porque era uma chuva de xingamentos. Mas tinha amigos também, que vinham falar comigo na linha do: "Ah, eu acho legal, mas pera aí...", principalmente em relação a essa coisa do escudo. $\mathrm{Na}$ época, eu lembro que a coisa estava tão insana, que outras pessoas já tinham me procurado, querendo fazer parte do grupo. Aí surgiu essa ideia de fazer uma enquete na página e se as pessoas não quisessem, a gente trocava. Um dos meus amigos que estava no grupo era designer, e depois que as pessoas realmente rejeitaram o escudo colorido, ele fez uma logo bonitinha, que é que tá atualmente... Foram alguns dias de muito muito assédio, de pessoas vindo falar comigo o tempo inteiro. As ameaças eram feitas $99 \%$ por homens e atleticanos. A gente recebia muito e, as vezes, ainda recebe mensagens falando que aquilo é coisa de cruzeirense: "Isso aí é coisa de "maria" pra sujar o nosso nome" (Nathália, Galo Queer). 


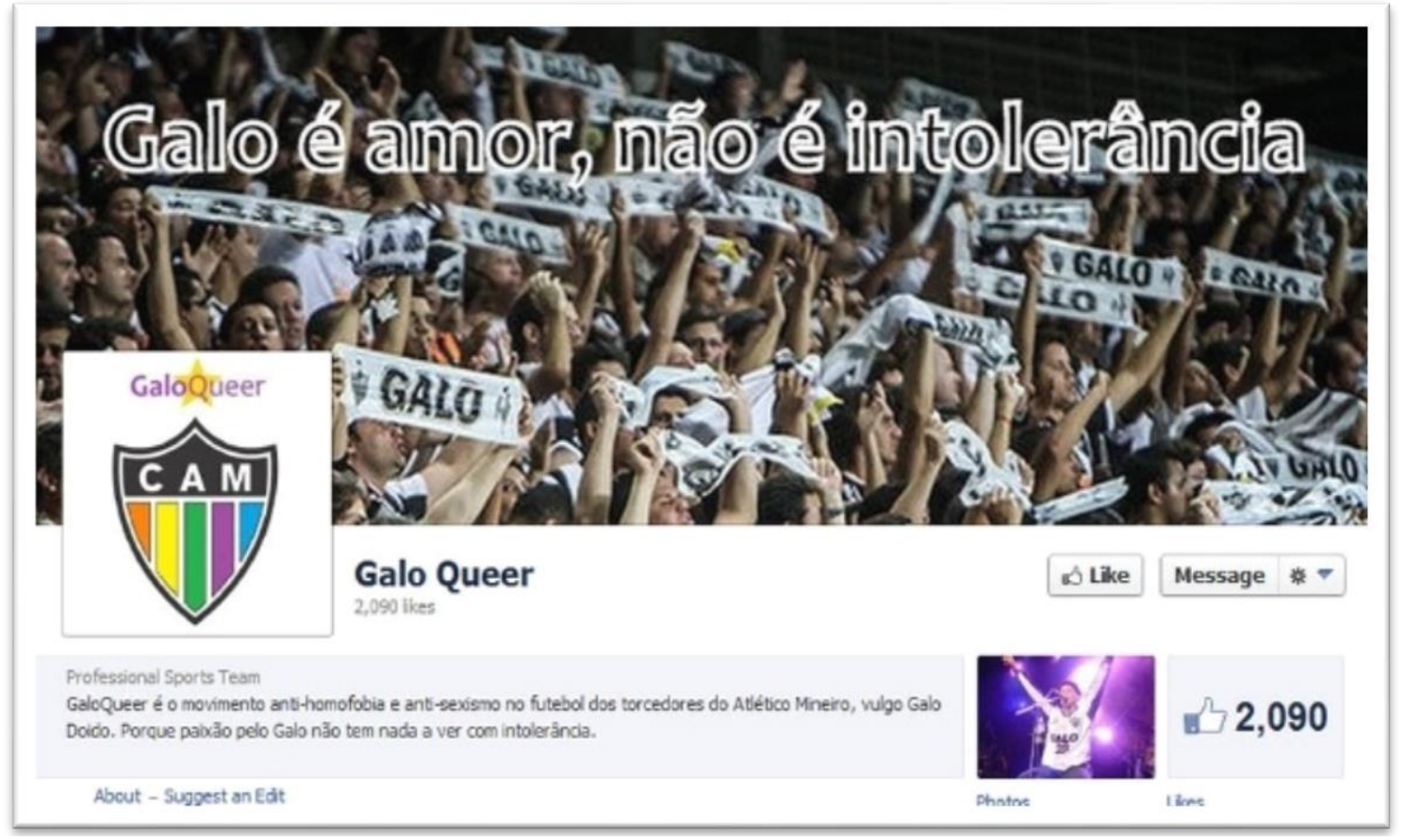

Figura 1 - Primeira versão da página Galo Queer, com o escudo do Atlético Mineiro colorido Fonte: Nathalia Duarte

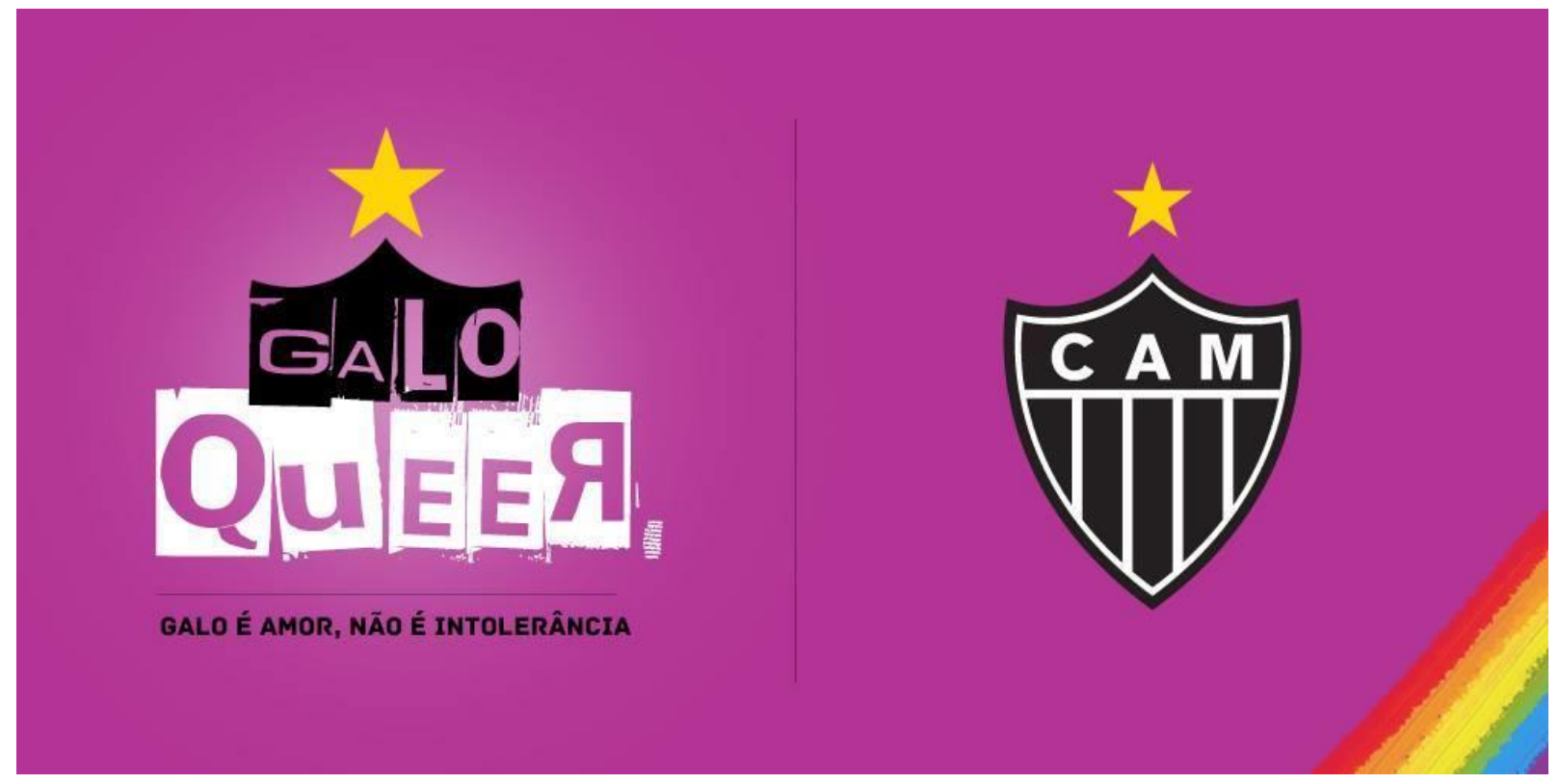

Figura 2 - Identidade visual que substituiu a primeira identidade visual da Galo Queer Fonte: Galo Queer (Facebook) ${ }^{17}$

\footnotetext{
${ }^{17}$ https://www.facebook.com/941232029242434/photos/a.941240279241609.1073741825.941232029242434/ 941240292574941/?type=1\&theater . Postagem de 03/05/2015. Acesso em 20/05/2017.
} 
Novos "sujeitos-torcedorxs": trajetórias e estratégias de visibilidade da Galo Queer, Bambi Tricolor e Palmeiras Livre

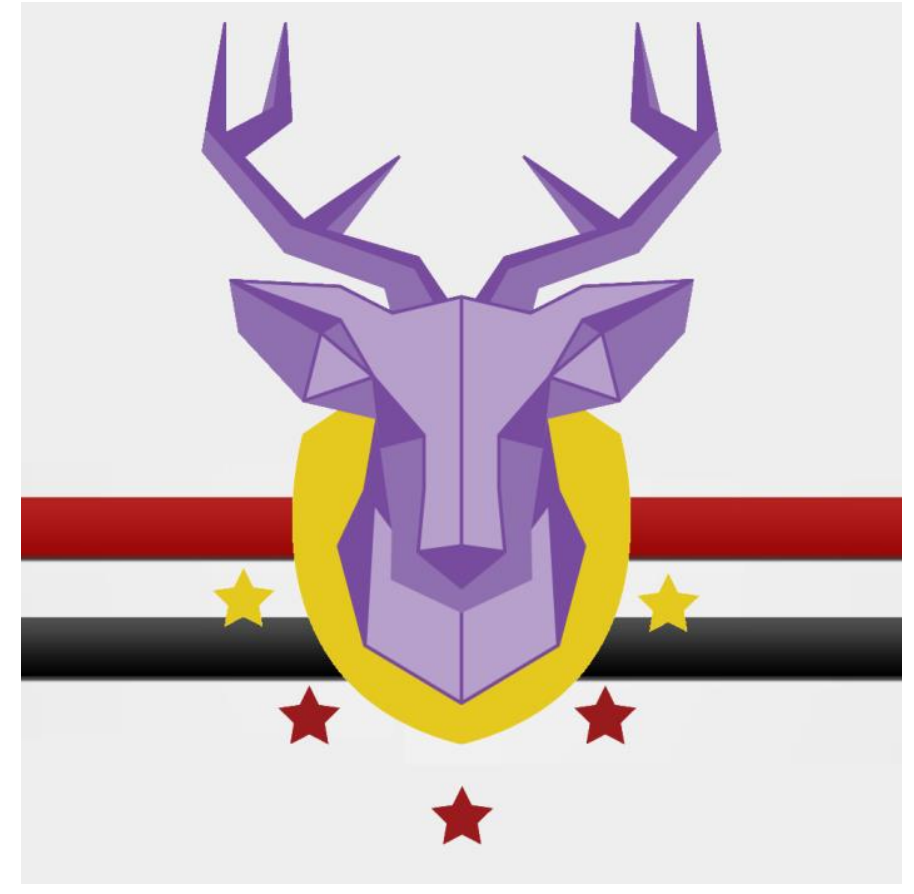

Figura 3 - Identidade visual atual da página Bambi Tricolor Fonte: Bambi Tricolor (Facebook) ${ }^{18}$

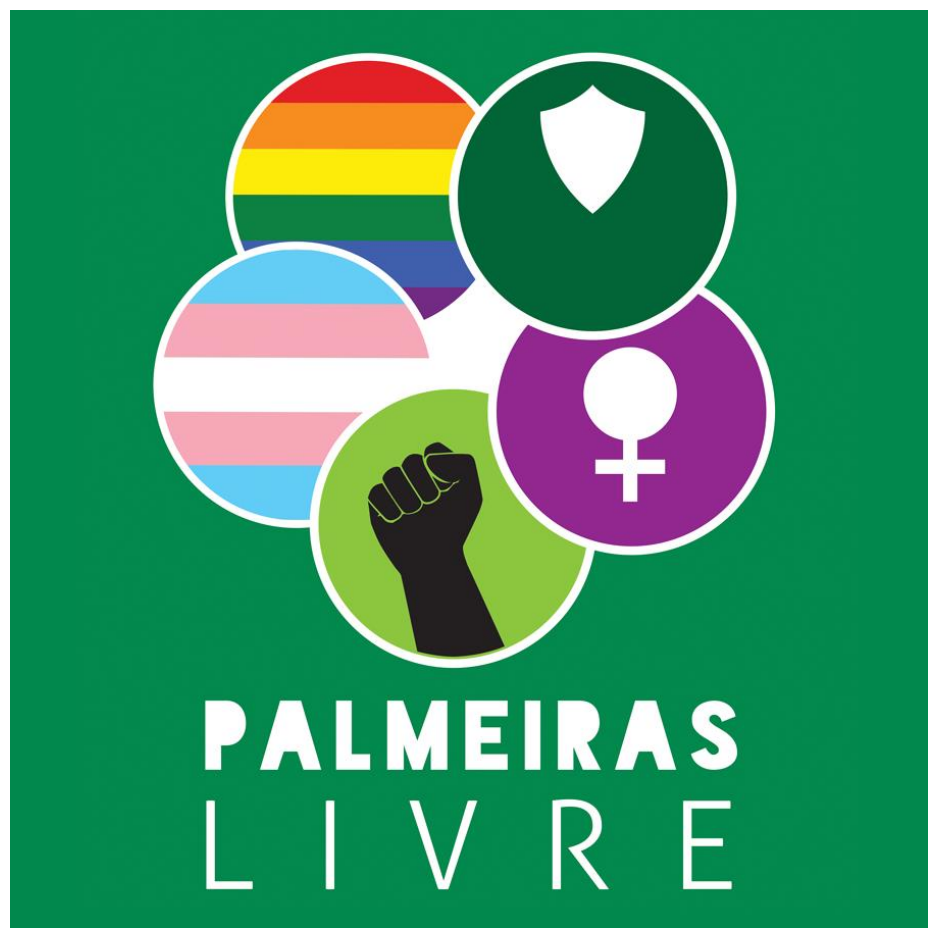

Figura 4 - Identidade visual do Palmeiras Livre, que faz referência aos símbolos dos movimentos LGBT, feminista, negro e transexual.

Fonte: Palmeiras Livre (Facebook) ${ }^{19}$

\footnotetext{
${ }^{18}$ https://www.facebook.com/BambiTricolor/photos/a.456957987718047.1073741825.456955007718345/6482 96975250813/?type=1\&theater. Postagem de 07/12/2016. Acesso em 20/05/2017.
} 
A rejeição e os discursos de ódio contrários à existência desses movimentos de torcedorxs que questionam e denunciam o machismo e a homofobia recorrentes no futebol brasileiro, são manifestadas por pessoas que agem como haters ${ }^{20}$ nas redes sociais. Para AMARAL e COIMBRA (2015, p. 300), o "comportamento sexual disruptivo é o alvo predileto do ataque dos haters, principalmente quando estes fogem dos padrões tidos como 'morais' por um determinado grupo social". Abaixo transcrevo alguns comentários públicos em resposta a postagens das páginas Palmeiras Livre, Galo Queer e Bambi Tricolor:

Que algumas páginas Palmeirense (sem citar nomes das tais páginas) não queria confudir [sic] o que acontece na Europa (Inglaterra) com o que acontece aqui... Nossa cultura é muito diferente, nosso estilo de ver futebol é diferente, nosso jeito de torcer é diferente... Não queria [sic] que nos tornemos burgueses de estádio em prol de meia dúzia... Futebol é a nossa paixão não queiram mistura-la a outros interesses, não queiram misturar isso com políticas, com algum tipo grupo... Vamos somente focar no PALMEIRAS... desculpem mais pra mim é assim FODA-SE direita FODA-SE a esquerda... FODA-SE PARTIDO (A ou B)... Político aprontou OK que seja preso por isso... Quando se tratar de PALMEIRAS AS ÚNICAS CORES SÃO VERDE E BRANCO... querem apoiar fulano ou beltrano OK não envolvam o nome da Sociedade Esportiva Palmeiras... Querem defender um grupo que se acham oprimidos pela nossa sociedade OK façam isso mais não usem o nome da Sociedade Esportiva Palmeiras como plataforma de apoio... (comentário enviado em 31/05/2017, por palmeirense ligado a torcida organizada do time em resposta à postagem sobre nota da torcida Mancha Alviverde a respeito do grito "Bicha" nas arquibancadas e as ofensas e ameaças homofóbicas sofridas por palmeirenses LGBT e pela própria página $)^{21}$.

Chupa gaylo, depois vem zoar o Cruzeiro, pelo menos não temos torcida gay $^{22}$.

\footnotetext{
${ }^{19}$ https://www.facebook.com/PalmeirasLivre/photos/a.523789234329431.1073741825.523788454329509/110 6482982726717/?type=1\&theater. Postagem de 17/05/2016. Acesso em 20/05/2017.

20 "O termo hater (em português, odiador) como gíria da internet é originário do hip hop norte-americano, e está relacionado à expressão "Haters Gonna Hate" (Odiadores vão odiar), e é utilizado para categorizar o sujeito que fala mal dos outros através dos espaços de interação e conversação na internet" (AMARAL; COIMBRA, 2015, p.300).

${ }^{21}$ Postagem do dia 29/05/2017, que recebeu 288 curtidas, 9 comentários e teve 17 compartilhamentos. O link para acesso à postagem é: <https://www.facebook.com/PalmeirasLivre/posts/1548851118489899>. Acesso em 30/09/2017.

${ }^{22}$ Comentário feito à postagem do dia 26/06/2015, que apresenta a identidade visual da Galo Queer estilizada com as cores do arco-íris, em homenagem ao Dia do Orgulho LGBT. A postagem recebeu 558 curtidas, 33 comentários e teve 36 compartilhamentos. Disponível em: <https://www.facebook.com/941232029242434/photos/a.941240279241609.1073741825.941232029242434/ 970308719668098/?type=1\&theater $>$. Acesso em 30/09/2017.
} 
Franga rosada depois chama a gente de Maria GAYLO ${ }^{23}$.

Mais vocês não são nadas [sic] mesmo, as únicas torcidas do são paulo que apoiam o time são: Dragões da Real, Independente, Movimento são paulino, Metal tricolor e torcida uniformizada do são paulo, Esses sim apoiam o time, e não ficam usando a equipe como forma de movimente [sic] contra homofobia. Nada contra, vocês só deviam criar uma pagina de gays e prontos, não querer falar por 20 milhões de torcedores, pq nao [sic] representam nem $1 \%$ disso, e nunca representaram [sic], cola no morumtri [sic] la que agente [sic] acaba rapidim com essa palhaçada hehe ${ }^{24}$.

Além de comentários ofensivos e violentos, outras ações de intimidação mais ostensivas foram colocadas em prática. No início de 2016, o acesso à página da Galo Queer foi bloqueado e, em seguida, a página foi deletada pelo Facebook. De acordo com Nathália, o Facebook não deu qualquer justificativa sobre a exclusão da página, o que implicou na perda de todo conteúdo produzido desde 2013. Além disso, a perda do vínculo com as pessoas que curtiam e seguiam a página, representou um "balde de água fria no movimento", que reduziu significativamente as suas ações no Facebook:

Simplesmente um dia, em janeiro de 2016, eu fui entrar na página para fazer uma postagem e a página original não existia mais. E o Facebook faz isso de forma muito arbitrária, não tem nenhuma forma de você recuperar. A gente chegou a consultar um advogado na época, para pensar em resgatar a página, só que não valia a pena, que as chances da gente conseguir eram pequenas para um trabalho muito grande. Acho que isso foi um grande balde de água fria no movimento também. Qual é a minha teoria? O Facebook tem uma política muito forte contra fakes ${ }^{25}$. Eu acho que começaram a denunciar a página como fake, ou de alguma forma descobriram qual era o perfil que hospedava a página, e começaram a denunciar como fake. Porque as denúncias de que era um conteúdo impróprio não faziam sentido. No começo teve muita denúncia e a página não chegou a ser tirada do ar por causa disso. Mas acho que quando eles viram essa possibilidade do fake... Eu não sei se de fato foi uma investida contra a página, mas eu acredito que sim. Como é que uma página desaparece do nada? Eu acho que foi isso que aconteceu e na época a gente ficou muito em dúvida sobre como proceder, o que fazer, não conseguimos informação nenhuma e aí acabamos optando por criar uma nova página, mas a página atual tem mais ou menos mil e poucas curtidas. Na outra a

\footnotetext{
${ }^{23}$ Idem nota 22.

${ }^{24}$ Comentário de são-paulino à postagem na qual a Bambi Tricolor critica frase de um diretor da Torcida Organizada Independente sobre a Bambi Tricolor em uma matéria publicada pela revista Placar. Postagem do dia 22/10/2013, que recebeu 97 curtidas, 18 comentários e 20 compartilhamentos. Disponível em: <https://www.facebook.com/BambiTricolor/photos/a.456985997715246.1073741828.456955007718345/5408 55135994998/?type=3> . Acesso em 30/09/2017.

${ }^{25}$ Fake em inglês significa "falso". O termo é usado para denominar contas ou perfis usados em redes sociais digitais com o propósito de ocultar a identidade real de um usuário.
} 
gente tinha mais de 10 mil. Então, o alcance da página diminuiu muito, foi uma perda muito grande (Nathalia, Galo Queer).

Já em junho de 2016, moderadores da página Palmeiras Livre tiveram seus perfis pessoais expostos e circulando entre pessoas ligadas à torcida organizada Mancha Alviverde, contrárias à existência da página. Tal fato ocorreu dias depois de uma postagem na qual o coletivo manifestou repúdio à presença do deputado federal e presidenciável, Jair Bolsonaro $^{26}$, em um jogo do Palmeiras, assim como pelo fato deste declarar-se palmeirense $^{27}$.

O objetivo de tal ação, além de intimidar integrantes do coletivo Palmeiras Livre, era também o de mostrar que estes estavam sendo monitorados, reforçando que 0 ambiente do estádio não seria um espaço seguro para a presença desses torcedorxs, tampouco para a exposição de símbolos e imagens que identifiquem o coletivo. Dessa forma, pretendia-se reafirmar o domínio masculino (cisgênero e pretensamente heterossexual) do espaço de torcer e, por meio da violência, "domesticar" a quem se dispusesse a afrontar a norma que produz e demarca os sujeitos e os não sujeitos no campo futebolístico.

Esse cenário culminou com ameaças e intimidações dirigidas diretamente ao perfil pessoal de Thaís e de outros moderadores da página, além de denúncias contra a página que resultaram no bloqueio provisório desta pelo Facebook. Thaís relata a sensação de "medo real" vivenciada pela primeira vez ao longo da sua experiência como ativista, o que exigiu um exercício de reflexão, além da tomada de algumas medidas:

Fiquei bem amedrontada. A gente conversou no grupo, falou: "Olha, a gente tem uma causa, a gente acredita em coisas, mas não temos vocação para mártir, vamos segurar um pouco". Tive que mudar nome no Facebook, ocultei as minhas publicações para preservar a minha filha, meu namorado, minha família. Isso durou um mês, até eu me reestabelecer por completo. Eu fiquei com medo de ir em estádio e de me expor mais ainda, porque afinal de contas eu estou aí dando minha cara em nome do Palmeiras Livre. Mas o medo real dura 24 horas. Eu não queria publicizar, não queria falar nada. Mas o pessoal que acompanha a página, me acolheu, me deu força... Resolvemos fazer um texto para publicar na nossa página. A gente não vai mais ter medo. Porque esse é o objetivo. Pessoalmente, fisicamente, não me fizeram nada, mas a gente não sabe quem são essas pessoas e do que elas são capazes de fazer. Eu fiz os meus contatos com

\footnotetext{
${ }^{26}$ Deputado federal pelo estado do Rio de Janeiro, cumprindo seu sexto mandato, Bolsonaro declarou-se palmeirense na ocasião. É conhecido pelos seus posicionamentos conservadores, como, por exemplo, a defesa da ditadura militar no Brasil e de práticas de tortura contra presos políticos, além de declarações homofóbicas e machistas.

27 Postagem feita em 03/06/2016. O link para acesso à postagem é: https://www.facebook.com/PalmeirasLivre/posts/1116985478343134. Acesso em 13/07/2016.
} 
pessoas ligadas diretamente a essa pessoa: 'Ih, desencana, isso aí só ladra, não faz nada, não acontece nada'. Mas é pra acreditar? Afinal de contas, a pessoa não faz nada, mas ela manda fazer, ela incita a violência. O futebol mexe com muita emoção e dentro da torcida organizada a gente tem um público muito misto. $A$ gente não sabe quem é cada um ali... A gente está até acostumado ao mesmo tipo de xingamento, sabe. "A Mancha tem que pegar vocês mesmo e enfiar a bandeira no cu para aprender a virar homem". Dessas coisas pra baixo... "Fica esperto, é melhor vocês não aparecerem no estádio...". Isso foi sempre muito genérico, nunca foi direcionado para alguém. Mas eles estavam falando para mim. "Feminista peluda, sapatão". "Ah, vou pegar para virar mulher" (Thaís, Palmeiras Livre).

Episódios como este mostram que o ciberespaço se configura como um campo de disputa em relação aos sentidos da prática torcedora e da conquista de reconhecimento do status de sujeito participante do campo futebolístico. Se por um lado, há produções discursivas e o esforço de naturalização do futebol como um reduto de "machos", por outro lado, a tomada da palavra feita por essas páginas revela que as suas práticas discursivas repercutem e também produzem desdobramentos cujo alcance vai além das redes sociais.

\section{Conclusão}

O presente artigo procurou mostrar a trajetória dos movimentos de torcedorxs contrários ao machismo e à homofobia no futebol brasileiro. Constituídos em 2013, em um contexto de efervescência política do país, relacionado a um maior uso das redes sociais digitais, para a manifestação de descontentamentos compartilhados e para a organização e articulação de manifestações políticas, estes movimentos construíram a sua visibilidade por meio do questionamento e desestabilização da norma da masculinidade hegemônica, que regula os atores estabelecidos do campo futebolístico, e pela reivindicação para si do direito de serem reconhecidos como sujeitos que compartilham da identidade torcedora, algo visto também como uma afronta pelos "torcedores de verdade".

Se as arquibancadas revelam-se lugares vedados à presença de grupos de torcedorxs que exponham tal posicionamento político ou expressem performatividades consideradas inadequadas ao ideal que visa naturalizar a ideia de que o futebol é um "jogo pra machos", é importante reconhecer que a internet e as redes sociais digitais constituíramse em importantes ferramentas de empoderamento e de construção de representatividade pelas quais pessoas em situação de maior precariedade constroem "regimes de visibilidade alternativos" às suas experiências e aos seus posicionamentos políticos, descolando-se das imagens e dos discursos preconceituosos e estigmatizantes (CARVALHO, 2015).

Dessa forma, a criação das páginas no Facebook e as interações e posicionamentos expressos na rede social, podem ser entendidos como estratégias pelas quais esses movimentos de torcedorxs contrários ao machismo e à homofobia no futebol contribuíram 
(e ainda contribuem) para a criação de novas referências e sentidos para o torcer e o fazer parte da experiência futebolística:

Em um futuro hipotético, a gente quer ter um espaço... Mas não estou falando um espaço com uma bandeira que a gente saia esfregando na cara de todo mundo, igual uma torcida organizada faz. Mas um espaço em que a gente possa se reunir, possa ver o jogo do Palmeiras, possa conversar no pré-jogo, no pós-jogo. No último jogo a gente conseguiu reunir 4, 5 pessoas. Foi super legal! Então que isso aconteça mais vezes e que isso aconteça com mais pessoas. Que mais pessoas que pensem como a gente e que tenham os mesmos anseios se reúnam e comecem a ocupar o espaço físico do futebol para que isso comece a mudar. Uma coisa sou eu sentado na arquibancada me incomodando com o cara do meu lado gritando "bicha" em um tiro de meta. Eu vou, no máximo, falar "Para de gritar, pô!" e vai ficar por isso mesmo. Se o cara quiser parar ele para, mas se ele não quiser, vai continuar gritando e eu não vou poder fazer nada. Mas acho que quando forem mais pessoas talvez esse comportamento mude, entendeu? Quando são 5 pessoas falando "Ow, olha o jogo!", a pessoa vai parar. Eu acho que quando têm várias pessoas juntas, o ambiente fica melhor, fica porque você está entre pessoas que você se identifica ali. Pessoas que você pode falar abertamente das suas questões, você pode ser você, não precisa ficar cheio de dedos. Pelo menos eu espero que isso possa acontecer um dia (Erick, Palmeiras Livre).

Artigo recebido em 28 fev. 2018.

Aprovado para publicação em 17 abr. 2018.

\section{Referências}

AMARAL, A; COIMBRA, M. Expressões de ódio nos sites de redes sociais: $O$ universo dos haters no caso \#eunãomereçoserestuprada. Contemporânea - Revista de Comunicação e Cultura. Salvador, v. 13, n. 3, p. 294-310, 2015. Disponível em http://dx.doi.org/10.9771/1809-9386contemporanea.v13i2.14010. Acesso em: 30 set. 2017. 
BUTLER, Judith. Quadros de guerra: quando a vida é passível de luto? Rio de Janeiro: Civilização Brasileira, 2016.

CARVALHO, Mario Felipe. Muito prazer, eu existo!: visibilidade e reconhecimento no ativismo de pessoas trans no Brasil. Tese (Doutorado em Saúde Coletiva) - Instituto de Medicina Social, Universidade do Estado do Rio de Janeiro, 2015.

CONNELL, R. MESSERSCHIMIDT, J. W. Masculinidade hegemônica: repensando o conceito. Revista Estudos Feministas, Florianópolis, v. 21, n.1, p. 241-282, janeiro-abril/2013. Disponível em http://dx.doi.org/10.1590/S0104-026X2013000100014. Acesso em 20 jun. 2017.

FRANCO JUNIOR, Hilário. A dança dos deuses: futebol, sociedade, cultura. São Paulo: Companhia das Letras, 2007.

MEIHY, José Carlos Sebe Bom. Manual de História Oral. São Paulo: Edições Loyola, 2000.

MISKOLCI, Richard. Estranhando as Ciências Sociais: notas introdutórias sobre Teoria Queer. Revista Florestan Fernandes, v. 2, p. 8-25, 2014.

. Teoria Queer: um aprendizado pelas diferenças. Belo Horizonte: Autêntica Editora, Universidade Federal de Ouro Preto (UFOP), 2013.

OMENA, E. Não foi só por 20 centavos: a "Copa das manifestações" e as transformações socioeconômicas. In: GAFFNEY, C.; SANTOS JÚNIOR, O. A.; RIBEIRO, L. C. Q. (Org.). Brasil: os impactos da Copa do Mundo 2014 e das Olimpíadas 2016. Rio de Janeiro: Observatório das Metrópoles, 2015, p. 203-218.

PINTO, Maurício Rodrigues; BONFIM, Aira. Pelo direito de torcer: A experiência de grupos e coletivos de torcedorxs de futebol contra a cultura de que futebol é coisa pra macho. Seminário Internacional Fazendo Gênero 11 \& 13th Women's Worlds Congress (Anais Eletrônicos). Florianópolis, 2017.

RANCIÈRE, Jacques. O desentendimento: Política e Filosofia. São Paulo: Editora 34, 1996.

RECUERO, Raquel. Redes sociais na internet. Porto Alegre: Sulina, 2009.

SINGER, André. Brasil, junho de 2013, classes e ideologias cruzadas. Novos estudos CEBRAP. São Paulo , n. 97, p.23-40, Nov. 2013. Disponível em http://www.scielo.br/pdf/nec/n97/03.pdf. Acesso em 26 mar. 2018. 